in public spaces and later jeopardized the lives of Mayas, I became disillusioned, and publicly broke with it in January 1984, speaking openly about the errors and moral turpitude of the leaders who carried out those heinous deeds. My modest trajectory as an ethical objector to dictatorship is not a secret: it appears in a paper I presented at the University of California, Santa Cruz (May 2001), in an article under consideration for $M L N$, and in a presentation at the MLA convention in 2001, in all of which I also summarize the documentation, public since 1985 , regarding the internal rupture in the EGP.

In the first paragraph of his letter, Stoll claims that he wanted to "encourage debate over representation in Latin American studies," yet in his book he makes incendiary statements that blame the violence on the defeated guerrillas: "If anyone ignited political violence in Ixil country, it was the Guerrilla Army of the Poor" (9), and "Rigoberta reinvented her family to personify EGP ideology" (198). Stoll's letter, like his book, is littered with errors of fact and with tropes that elicit knee-jerk reactions, such as the mention of "Havana." Few PMLA readers know that Cuban scholars never theorized testimonio but limited themselves to reproducing American articles in Spanish. Stoll also attributes to me a definition of testimonio that comes from John Beverley, the scholar who first objected to Stoll's papers in the early 1990s. I did not participate in that debate, nor was I part of the group of academics that debated testimonio in the 1990s, a fact easily verified by examining bibliographies on the topic. Stoll also asserts that scholars like me are "hostile to other Mayan perspectives on the violence." After 1984, however, I disagreed politically with Menchú, and we did not speak to each other for ten years. I moved in the direction of Maya identity politics, as Kay Warren, from Harvard, has documented in her text about the emergence of the Maya movement. Finally, it is clear that Stoll did not read my article carefully. I never accused him of interviewing peasants in the presence of Guatemalan soldiers or in the offices of AID, but I did mention in a Guatemalan newspaper (not in an academic article) that an informant claims to have seen him interviewing in a pension routinely used by Guatemalan intelligence and says that he presented himself as an AID officer.

Who has the authority to make truth claims? How can we speak our truth and allow others to speak theirs as well? How can we allow the disempowered to make themselves heard without violence? It saddens me to see these important issues reduced to politics and, worse still, to academic politics. Stoll's innuendos seek to discredit those of us-Mayas, Central Americans, women - who have dared to raise our voices, and his misrepresentations desecrate the graves of the massacred victims, nearly all of whose deaths the United Nations' Truth Commission report has attributed to the Guatemalan army. Unfortunately, his indirect methods work: high schools, community colleges, and even universities in the United States have stopped teaching Menchú's text, despite its basic truths.

Guatemalans lived the opposition to a brutal, racist, and murderous dictatorship not as a distant or exotic adventure but as a life's ethical commitment. In the process we lost loved ones, close friends, relatives, our own illusions, and our youth. We welcome public debate on the issues, which offer an important lesson about the present situation in the Middle East, but we do not take kindly to Stoll's callous and factually inaccurate portrayal of our national tragedy.

Arturo Arias University of Redlands

\section{Huckleberry Finn}

\section{To THE EDITOR:}

At the 1995 American Literature Association convention in Baltimore, I presented a paper entitled "The Figure Forty in Huckleberry Finn," in which I argued that, among other reasons for using the figure forty, Mark Twain was frequently making quiet but conscious structural use of and reference to the phrase "forty acres and a mule." Before this, scholars such as Dan- 
iel G. Hoffman, Thomas Werge, Pascal Covici, Victor Doyno, Arthur G. Pettit, and Harold Beaver had concentrated their attention on three appearances of the figure in the novel in connection with Jim and money and had dealt primarily with the occasions on which the number occurred in that context. No previous scholar, as far as I could ascertain, had undertaken to justify the claim that Twain's repeated use of the number could be directly and significantly linked to "forty acres and a mule"; only James F. Light, in a parenthetical remark, had entertained the possibility that the forty dollars for Jim at the end of the novel was at least "reminiscent" of the phrase ("Paradox, Form, and Despair in Huckleberry Finn," Mark Twain Journal 21.4 [1983]: 25). Moreover, to my knowledge, no scholar had ever before drawn attention to the many additional contexts in the novel where the figure forty appears or to possible grounds for such repetition. (My paper appeared, under its original title, as ch. 7 of my book Refiguring Huckleberry Finn [U of Georgia P, 2000].)

It was therefore of interest to me to discover several aspects of my argument incorporated, unattributed, into the closing segment, "“Forty Acres and a Mule,", of Stacey Margolis's recent PMLA article "Huckleberry Finn; or, Consequences" (116 [2001]: 329-43). I realize that Newton and Leibniz developed the foundations of differential and integral calculus independently and almost simultaneously, but since there appears to be no simultaneity in this case, certain questions come to mind: Was Margolis in the audience at Baltimore? If not, through what other channel might she have learned of my research? Why does Margolis acknowledge no other scholar's earlier work on Twain's multiple use of the figure forty and thereby create the impression that she is plowing an uncultivated field? I am aware that new and interesting ideas, once placed in the public domain, can swiftly take wing and travel widely, and this caused me some concern before I presented my unpublished results in Baltimore. I would therefore welcome Margolis's word-not sworn on a dictionary - that she arrived independently at the conclusion that she now presents as original and as no longer subject to doubt: "Surely forty is meant to recall the promise of forty acres and a mule, which were to make the freedmen equal as well as free" (339).

Carl F. Wieck

University of Tampere

\section{TO THE EDITOR:}

Stacey Margolis argues persuasively that Twain's rejection of the "politics of good intentions" lies at the base of some critical attacks on the prominence of Adventures of Huckleberry Finn. Twain himself powerfully supports her argument in two comments in his writings. Discussing the life of Hannibal, Missouri, in his childhood, for example, he denies that slavery was "evil": "It is commonly believed that an infallible effect of slavery was to make such as lived in its midst hard-hearted. I think that it had no such effect-speaking in general terms. I think it stupefied everybody's humanity, as regarded the slave, but stopped there" (Mark Twain's Hannibal, Huck and Tom, ed. Walter Blair [Berkeley: U of California P, 1969] 50). His primary example was his mother, notable for her kindheartedness to slaves and animals. Tom Sawyer at the end of Adventures of Huckleberry Finn is predictably stupid ("intellectural," he says); the yokels at the end of the novel are stupefied-those cases are easy to spot. Aunt Sally and Uncle Silas are also stupefied. Huck, too, is stupefied, acknowledging that the doctor who treats Tom "had a good heart in him and was a good man" (ch. 42). Commending Jim in a speech that Huck applauds, the doctor, of course using classic code words of the segregated, discriminatory South, says twice that "he ain't a bad nigger." All the characters in this novel are stupefied to the humanity of the "nigger" because he is "a nigger." Twain's satire is unpalatable because of its truthfulness to the blindness of his characters. As Twain pointed out in "A True Story," a decade before, whites and blacks have very different perceptions of black experience. 